\title{
Social Contacts and Achievement of Design Professionals
}

\author{
Chan-Jyuan Jhang, Rain Chen, Ting-Yu Sung, Chia-Chun Lin \\ Southern Taiwan University of Science and Technology, Taiwan, R.O.C.
}

\begin{abstract}
The study examined which social contact, strong ties vs. weak ties, is positive and advantageous for designers' professional achievement. The investigators also tested if a designer's professional achievement is correlated with his or her professional contacts (strong ties) or non-professional contacts (weak ties). A designer's professional and non-professional contacts in the study were represented by the ratios of design professional and of non-design professional friends on Facebook, respectively, to the total number of Facebook friends. Correlation analysis was performed to examine if the number of professional and of non-professional contacts (the ratios of design professional friends and of non-design professional friends on Facebook) of 35 student designers is correlated with their professional design achievement (their graduation project grades). The study results show that neither professional nor non-professional contacts (design professional friends vs. non-design professional friends) was significantly correlated with designers' professional design achievement. Nonetheless, there was a positive correlation between the size of contacts and professional design achievement. This finding can help design educators recognize the importance of social network development in design education and training.
\end{abstract}

Keywords: strong ties, weak ties, professional contacts, professional achievement, design education

\section{Introduction}

The design industry has become more matured, thanks to the fast development and the trend of globalization, while consumers' design product consumption and demands also increase quickly. Design has shifted from style variation oriented to the more complicated emotional design. As the design industry becomes more globalized, it is important to recognize that an excellent product design, i.e., winning the market, depends heavily upon the incorporation of multi-value chains.

In terms of the life style of product designers, it is common for them to stay up late. Designers have to spend time to learn about not only various related industries but also many hand-on skills. Nevertheless, designers in Taiwan are suffering from wages that are not proportional to their design expertise. Is it because a designer's work attitude and social contact are ignored because of an overemphasis on hand-on skills, hand-drawn graphic skills, or CAD during the professional training of designers?

Skills are always treated as the foundation in the professional education of product designers. In fact, there aren't many courses on interpersonal skills available. Moreover, technology universities in Taiwan tend to pay little or no attention on humanism, which, together with interpersonal communication, unfortunately, do play a critical role in determining the successfulness of a designer.

Chan-Jyuan Jhang, Department of Creative Product Design, Southern Taiwan University of Science and Technology. Rain Chen, Ph.D., Department of Creative Product Design, Southern Taiwan University of Science and Technology. Ting-Yu Sung, Department of Creative Product Design, Southern Taiwan University of Science and Technology. Chia-Chun Lin, Ph.D., Department of Creative Product Design, Southern Taiwan University of Science and Technology. 
Relevant researchers have pointed out that personality is a critical factor of professional design achievement (Tsai, 2011). Figure 1 shows the analysis of weighted industrial design abilities summarized by Tsai (2011). It can be found that personality traits are the second most important industrial design ability right after product planning.

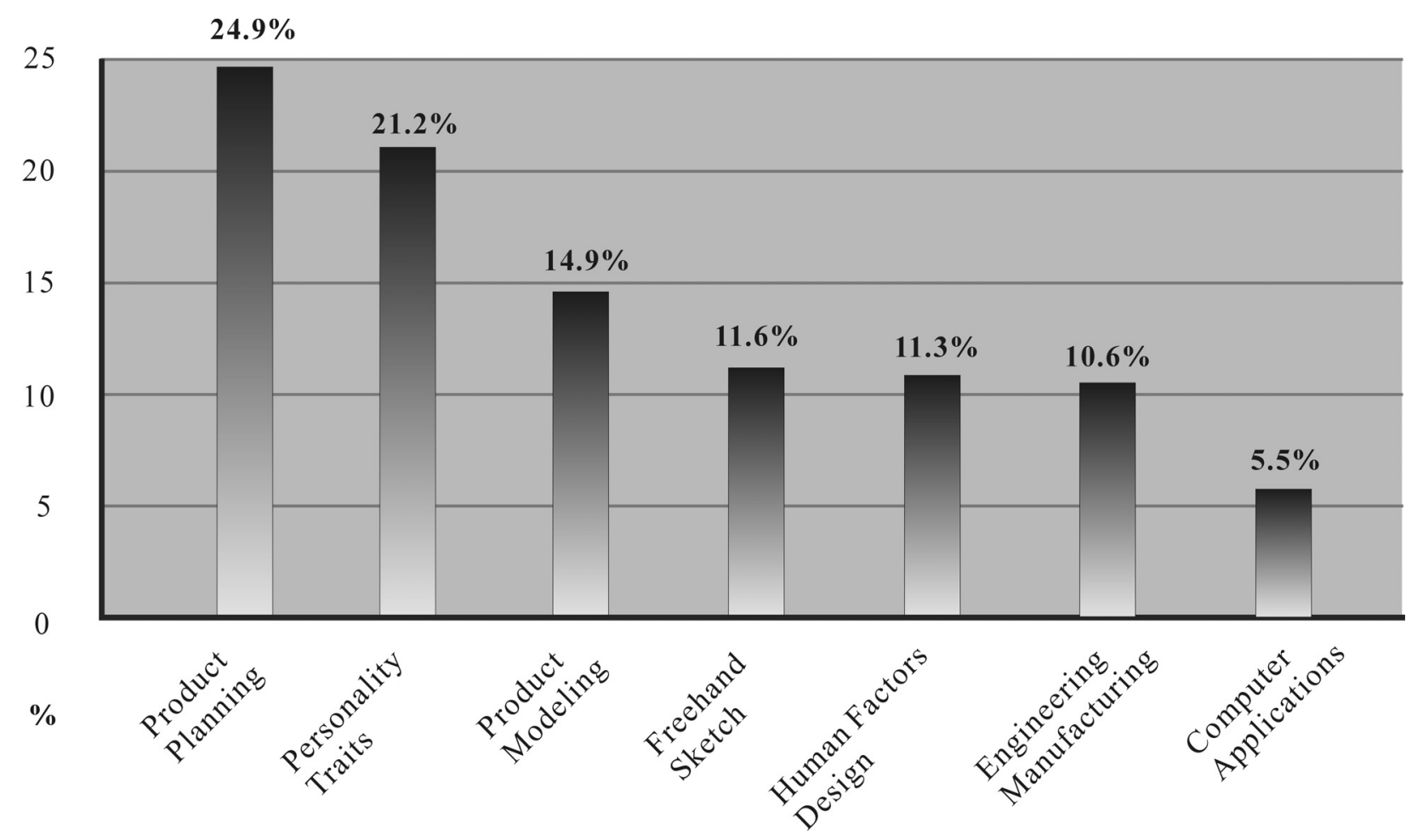

Figure 1. Weighted industrial design abilities.

In recent years, improving the design research and development competence has become a critical factor for upgrading industries. Industry design competence, on the other hand, is crucial in industrial transformation, upgrade, and competitiveness improvement. What is valued the most in the industrial design sector is personality traits, which is followed by style design competence and innovative design competence (Kao, 2012). Kao (2012) demonstrated that personality traits are far more important than design skills for design professionals.

Among studies on interpersonal relationship, "The Strength of Weak Ties" has been cited for more than 20,000 times, making it probably the most frequently cited social science paper (Guokr, 2014). Mark Granovetter found that strong ties, such as associations with family and friends, are not as useful as weak ties. This study pointed out that among people who got their jobs by connection, only $38 \%$ of them relied on strong ties; the remaining 52\% used weak ties (Baidu, 2014).

\section{Methods}

Social network is not just an important social science concept for studies on interpersonal interaction and information exchange models; it is also greatly valued in the organization and human resource research field. Studies have shown that weak ties play a key role in the process of information exchange by acting as a bridge that links people to heterogeneous information and improves their innovative behavior (Liu, 2007). 
In the book Superconnect: In Harnessing the Power of Networks and the Strength of Weak Links by Richard Koch and others, the authors stated that their success can be attributed to old colleagues whom they had not been in touch for long but were suddenly bumped into. The book Superconnect described new rules for concentrated social contacts and analyzed three core concepts: strong ties, weak ties, and hubs of social networks. The author explained how a social network acts as a bridge that connects total unrelated people to each other (Koch \& Lockwood, 2010).

The main theme of the study is to design professionals' social contacts and achievement, while the key question the investigators like to answer is whether more professional contacts mean better design performance. Granovetter's paper "The strength of weak ties: a network theory revisited" in 1973 explored the relation between strong ties and weak ties and discussed how Boston suburb residents found their jobs. Granvovetter pointed out that most residents got their jobs through weak ties; those whom they are closely related to, i.e., strong ties, were not very helpful in this aspect. The author also found that the rich often keep in touch with pluralistic weak ties (Granovetter, 1973).

The main objective of the study is to identify which type of contact, strong ties or weak ties, is more positive and advantageous for professional design performance. Practically, social network is a term hard to define, and moreover, because the present study would like to adopt a quantitative approach, the investigators decided to define a designer's professional contacts as the ratio of his or her design professional friends on Facebook to all the Facebook friends. This ratio was then compared with the designer's design achievement.

The study is focused on the designer's professional and non-professional contacts. The ratios of design professional and of non-design professional friends to the total number of friends on Facebook were calculated. In this study, professional contacts (friends who are design professionals) were referred to as strong ties, while non-professional contacts (friends who are non-design professionals) were weak ties. The objective of the study is to explore if a designer's professional design achievement is influenced by his or her professional and non-professional contacts.

The study obtained 35 design students' grades from the graduation project course taken in their senior year. Because the graduation project is like a final exam for design-major students, it can concretely reflect students' design competence. The study used correlation analysis to test if a designer's professional and non-professional contacts (ratios of design professional friends and of non-professional friends on Facebook) are correlated with their professional design performance. The results may serve as a reference for revising design courses in the near future.

\section{Result}

The study used correlation coefficients and correlation analysis as the research tools. The goal is to test if a designer's professional and non-professional contacts are correlated with his or her professional design performance. The study also examined if professional contacts are positively correlated with professional design achievement. In terms of the gender of the test subjects, 15 out of the 35 subjects were males (43\%), while 20 out of the 35 subjects were females (57\%) (see Table 1).

The study calculated the ratios of professional contacts (design professional friends) and non-professional contacts (non-design professional friends) on Facebook, respectively. Designers' professional design achievement (their grades from the graduation project course) was included in the statistical analysis (see Table 2). Table 3 for descriptive statistical results. 
Table 1

Gender of Test Subjects

\begin{tabular}{llccc}
\hline & Frequency & Percent & Valid percent & Cumulative percent \\
\hline Male & 15 & 42.9 & 42.9 & 42.9 \\
Female & 20 & 57.1 & 57.1 & 100.0 \\
Total & 35 & 100.0 & 100.0 & \\
\hline
\end{tabular}

Table 2

Original Data of Test Subjects' Contacts and Professional Achievement

\begin{tabular}{|c|c|c|c|c|c|c|c|}
\hline No. & $\begin{array}{l}\text { Sex } \\
(\mathrm{M} / \mathrm{F})\end{array}$ & $\begin{array}{l}\text { Professional } \\
\text { Contacts, PC }\end{array}$ & $\begin{array}{l}\text { Non- Professional } \\
\text { Contacts, NC }\end{array}$ & $\begin{array}{l}\text { Total } \\
\text { Contacts, } \\
\text { TC }\end{array}$ & $\begin{array}{l}\text { Professional } \\
\text { Contacts Ratio, } \\
\text { PCR }\end{array}$ & $\begin{array}{l}\text { Non- Professional } \\
\text { Contacts Ratio, NCR }\end{array}$ & $\begin{array}{l}\text { Professional } \\
\text { Achievement, PA }\end{array}$ \\
\hline 1 & $\mathrm{~F}$ & 355 & 1523 & 1878 & 0.19 & 0.81 & 85 \\
\hline 2 & $\mathrm{~F}$ & 397 & 131 & 528 & 0.75 & 0.25 & 80 \\
\hline 3 & $\mathrm{~F}$ & 230 & 200 & 430 & 0.53 & 0.47 & 70 \\
\hline 4 & $\mathrm{~F}$ & 94 & 122 & 216 & 0.44 & 0.56 & 73 \\
\hline 5 & $\mathrm{~F}$ & 220 & 233 & 453 & 0.49 & 0.51 & 68 \\
\hline 6 & $\mathrm{~F}$ & 108 & 108 & 216 & 0.50 & 0.50 & 45 \\
\hline 7 & $\mathrm{~F}$ & 250 & 500 & 750 & 0.33 & 0.67 & 74 \\
\hline 8 & $\mathrm{~F}$ & 91 & 161 & 252 & 0.36 & 0.64 & 72 \\
\hline 9 & $\mathrm{~F}$ & 80 & 51 & 131 & 0.61 & 0.39 & 70 \\
\hline 10 & $\mathrm{~F}$ & 100 & 300 & 400 & 0.25 & 0.75 & 72 \\
\hline 11 & $\mathrm{~F}$ & 100 & 200 & 300 & 0.33 & 0.67 & 74 \\
\hline 12 & $\mathrm{~F}$ & 200 & 634 & 834 & 0.24 & 0.76 & 74 \\
\hline 13 & $\mathrm{~F}$ & 130 & 72 & 202 & 0.64 & 0.36 & 69 \\
\hline 14 & $\mathrm{~F}$ & 124 & 83 & 207 & 0.60 & 0.40 & 73 \\
\hline 15 & $\mathrm{~F}$ & 100 & 100 & 200 & 0.50 & 0.50 & 75 \\
\hline 16 & $\mathrm{~F}$ & 220 & 315 & 535 & 0.41 & 0.59 & 73 \\
\hline 17 & $\mathrm{~F}$ & 400 & 100 & 500 & 0.80 & 0.20 & 79 \\
\hline 18 & $\mathrm{~F}$ & 163 & 186 & 349 & 0.47 & 0.53 & 87 \\
\hline 19 & $\mathrm{~F}$ & 100 & 249 & 349 & 0.29 & 0.71 & 72 \\
\hline 20 & $\mathrm{~F}$ & 103 & 343 & 446 & 0.23 & 0.77 & 90 \\
\hline 21 & $\mathrm{M}$ & 122 & 312 & 434 & 0.28 & 0.72 & 54 \\
\hline 22 & $\mathrm{M}$ & 110 & 368 & 478 & 0.23 & 0.77 & 68 \\
\hline 23 & $\mathrm{M}$ & 55 & 425 & 480 & 0.11 & 0.89 & 86 \\
\hline 24 & $\mathrm{M}$ & 102 & 143 & 245 & 0.42 & 0.58 & 83 \\
\hline 25 & $\mathrm{M}$ & 17 & 22 & 39 & 0.44 & 0.56 & 87 \\
\hline 26 & $\mathrm{M}$ & 133 & 251 & 384 & 0.35 & 0.65 & 63 \\
\hline 27 & $\mathrm{M}$ & 82 & 200 & 282 & 0.29 & 0.71 & 35 \\
\hline 28 & $\mathrm{M}$ & 60 & 230 & 290 & 0.21 & 0.79 & 71 \\
\hline 29 & $\mathrm{M}$ & 82 & 173 & 255 & 0.32 & 0.68 & 71 \\
\hline 30 & $\mathrm{M}$ & 145 & 166 & 311 & 0.47 & 0.53 & 71 \\
\hline 31 & $\mathrm{M}$ & 130 & 410 & 540 & 0.24 & 0.76 & 70 \\
\hline 32 & $\mathrm{M}$ & 600 & 56 & 656 & 0.91 & 0.09 & 70 \\
\hline 33 & $\mathrm{M}$ & 75 & 285 & 360 & 0.21 & 0.79 & 68 \\
\hline 34 & $\mathrm{M}$ & 100 & 376 & 476 & 0.21 & 0.79 & 74 \\
\hline 35 & $\mathrm{M}$ & 85 & 137 & 222 & 0.38 & 0.62 & 72 \\
\hline
\end{tabular}


Table 3

Descriptive Statistics on Test Subjects' Contacts and Professional Achievement

\begin{tabular}{llrrrllr}
\hline & $\begin{array}{l}\text { Sex } \\
(\mathrm{M} / \mathrm{F})\end{array}$ & $\begin{array}{l}\text { Professional } \\
\text { contacts, PC }\end{array}$ & $\begin{array}{l}\text { Non- } \\
\text { professional } \\
\text { contacts, NC }\end{array}$ & $\begin{array}{l}\text { Total contacts, } \\
\text { TC }\end{array}$ & $\begin{array}{l}\text { Professional } \\
\text { fontacts ratio, } \\
\text { PCR }\end{array}$ & $\begin{array}{l}\text { Non-professional } \\
\text { contacts ratio, } \\
\text { NCR }\end{array}$ & $\begin{array}{l}\text { Professional } \\
\text { achievement, PA }\end{array}$ \\
\hline $\begin{array}{l}\text { Mean } \\
\text { Std. Error of }\end{array}$ & 1.57 & 156.09 & 261.86 & 417.94 & 0.40 & 0.60 & 71.94 \\
$\begin{array}{l}\text { Mean } \\
\text { Std. }\end{array}$ & 20.08 & 43.71 & 51.66 & 0.03 & 0.03 & 1.83 \\
$\begin{array}{l}\text { Deviation } \\
\text { Variance }\end{array}$ & 0.50 & 119.31 & 258.61 & 305.61 & 0.19 & 0.19 & 10.82 \\
Range & 0.25 & 14234.90 & 66880.77 & 93398.41 & 0.03 & 0.03 & 117.06 \\
Minimum & 1.00 & 583.00 & 1501.00 & 1839.00 & 0.80 & 0.80 & 55.00 \\
Maximum & 2.00 & 17.00 & 22.00 & 39.00 & 0.11 & 0.09 & 35.00 \\
\hline
\end{tabular}

Correlation analysis results are presented in Tables 4 and 5. A correlation coefficient close to zero means a lack of correlation. The Pearson correlation coefficient between the professional contacts ratio and professional design achievement was 0.005 , while the value between the non-professional contacts ratio and professional design achievement was -0.005 . Therefore, neither the professional contacts ratio and professional design achievement nor the non-professional contacts ratio and professional design achievement were correlated. According to the level of significance, on the other hand, more contacts mean better professional design achievement (i.e., a positive correlation) regardless of the type of contacts, i.e., professional or non-professional.

Table 4

Correlation Analysis of Professional Contacts Ratio and Professional Achievement

\begin{tabular}{|c|c|c|c|}
\hline $\mathrm{PCR} / \mathrm{PA}$ & Items & Professional contacts ratio, PCR & Professional achievement, PA \\
\hline \multirow{5}{*}{$\begin{array}{l}\text { Professional contacts ratio, } \\
\text { PCR }\end{array}$} & Pearson Correlation & 1 & 0.005 \\
\hline & Sig. (2-tailed) & & 0.977 \\
\hline & $\begin{array}{l}\text { Sum of Squares and } \\
\text { Cross-products }\end{array}$ & 1.170 & 0.352 \\
\hline & Covariance & 0.034 & 0.010 \\
\hline & $N$ & 35 & 35 \\
\hline \multirow{5}{*}{ Professional achievement, PA } & Pearson Correlation & 0.005 & 1 \\
\hline & Sig. (2-tailed) & 0.977 & \\
\hline & $\begin{array}{l}\text { Sum of Squares and } \\
\text { Cross-products }\end{array}$ & 0.352 & 3979.886 \\
\hline & Covariance & 0.010 & 117.055 \\
\hline & $N$ & 35 & 35 \\
\hline
\end{tabular}

Table 5

Correlation Analysis of Non-professional Contacts Ratio and Professional Achievement

\begin{tabular}{llcc}
\hline NCR/PA & Items & $\begin{array}{l}\text { Non-professional contacts ratio, } \\
\text { NCR }\end{array}$ & Professional achievement, PA \\
\hline & Pearson correlation & 1 & -0.005 \\
& Sig. (2-tailed) & & 0.977 \\
Non-professional contacts & Sum of Squares and & 1.170 & -0.352 \\
ratio, NCR & Cross-products & 0.034 & -0.010 \\
& Covariance & 35 & 35 \\
\hline
\end{tabular}


Table 5 to be continued

\begin{tabular}{lllc}
\hline NCR/PA & Items & Non-professional contacts ratio, & Professional achievement, PA \\
\hline & Pearson Correlation & -0.005 & 1 \\
& Sig. (2-tailed) & 0.977 & \\
& Sum of Squares and & -0.352 & 3979.886 \\
Professional Achievement, PA & Cross-products & -0.010 & 117.055 \\
& Covariance & 35 & 35 \\
$N$ & &
\end{tabular}

\section{Discussion and Conclusion}

Mark Granovetter considered that more diverse weak ties could enhance heterogeneity, which in turns is associated with better career performance or business venture. According to Granovetter's theory, having more non-design professional friends is advantageous because they can provide more pluralistic and innovative design ideas.

The Pearson correlation coefficient result of the study demonstrated that neither professional contacts (design professional friends) nor non-design professional contacts (non-design professional friends) were significantly correlated with professional design achievement. There are two possible explanations. First, the sample size of the study is too small to detect the correlation. Secondly, professional contacts cannot well represent strong ties and same for non-design professional contacts and weak ties.

Although the results here show a lack of direct link between the type of ties and professional design achievement, there was a positive correlation between the size of contacts and professional design achievement. This finding can help design educators recognize the importance of social network development in design education and training.

\section{References}

Baidu. (2014). Weak ties. Retrieved from http://baike.baidu.com/view/9696410.htm

Granovetter, M. S. (1973). The strength of weak ties. The American Journal of Sociology, 78(6), 1360-1380.

Guokr (2014). Far better than the next of kin neighbor: The key contacts are unfamiliar friend. Retrieved from http://www.guokr.com/article/338387/

Kao, P. H. (2012). A proposal of pre-service self-assessment scale for industrial designers (Thesis of Ling Tung University, pp. $1-83)$.

Koch, R., \& Lockwood, G. (2010). Superconnect: Harnessing the power of networks and the strength of weak links. W. W. Norton \& Company.

Liu, S. F. (2007). The impact of weak ties on innovative instructional behavior foruniversity's teacher: The moderating effect of cognitive styles (Thesis of National Chung Cheng University, pp. 1-126).

Tsai, C. C. (2011). A study of ability requirement of industry design in product life cycle-A case study of the Motorcycle (Thesis of National Kaohsiung University of Applied Sciences, pp. 1-95). 